\title{
Bacterial 16S rDNA Sequences in Immature Volcanic Ash Soil on Volcanoes Mt. Sakurajima and Mt. Fugen in Japan Determined by PCR Amplification
}

\author{
Masaya Nishiyama ${ }^{1}$, Yuko Watanabe, and Takuya Marumoto \\ Faculty of Agriculture, Yamaguchi University, Yamaguchi, 753-8515 Japan
}

Received June 9, 1998; accepted in revised form August 19, 1998

Volcanogenous soils are widely distributed in Japan. Andosols, a group of volcanogenous soil, are known to show several physicochemical characteristics such as high porosity, presence of allophane, and high content of organic carbon (FitzPatrick 1980). The formation of Andosols is a very rapid process resulting from the large surface area of the volcanic ash-derived parent materials.

Also volcanogenous soils exhibit several microbiological characteristics. Ishizawa and Toyoda (1964) reported that the bacterial counts obtained by the culture method were smaller in volcanogenous than in non-volcanogenous soils while the counts of actinomycetes and anaerobes were higher. We were interested to determine what kinds of microorganisms are involved in soil formation. In this study, we aimed at analyzing the bacterial community in immature volcanic ash soils. A culture-independent, 16S rDNA analysis method was adopted because it is well known that only a part of the bacteria in soil can be cultured and because we anticipated that the population of culturable bacteria was small due to the low content of organic matter in the soil samples used in this study. Rhizobacteria of the pioneer plants in the low-nutrient immature volcanic ash soils were also investigated.

Samples from soils or plant roots were taken on Mt. Fugen in June 1996 and on Mt. Sakurajima in October 1996, both located in the Kyushu district of Japan. At Mt. Fugen, strong eruptions occurred in 1990-1991, when pyroclastic flows destroyed the pre-eruption vegetation. In 1996, the sampling area was covered with patches of a few plant species such as Polygonum cuspidatum, Eragrostis curvula, and Paspalum spp. Mount Sakurajima has been erupting intermittently and the sampling area was covered with patches of Miscanthus sinensis. On those sites, immature volcanic ash soils $\left(1-10 \mathrm{~cm}\right.$ depth; $\mathrm{Mt}$. Fugen: $\mathrm{pH}\left(\mathrm{H}_{2} \mathrm{O}\right)$ 5.0 , organic $\mathrm{C} 0.15 \%$, aerobic bacteria on $\mathrm{YG}$ agar (yeast extract $1.0 \mathrm{~g}$, glucose $1.0 \mathrm{~g}, \mathrm{~K}_{2} \mathrm{HPO}_{4}$ $0.3 \mathrm{~g}, \mathrm{KH}_{2} \mathrm{PO}_{4} 0.2 \mathrm{~g}, \mathrm{MgSO}_{4} \cdot 7 \mathrm{H}_{2} \mathrm{O} 0.2 \mathrm{~g}$, agar $15.0 \mathrm{~g}$, distilled water $\left.1,000 \mathrm{~mL}, \mathrm{pH} 6.8\right) 1.3 \times$ $10^{6} \mathrm{cfu}$ per g; Mt. Sakurajima: $\mathrm{pH}\left(\mathrm{H}_{2} \mathrm{O}\right) 4.5$, organic $\mathrm{C} 0.08 \%$, aerobic bacteria on $\mathrm{YG}$ agar $6.0 \times 10^{4} \mathrm{cfu}$ per $\mathrm{g}$ ) and plant roots ( $P$. cuspidatum on Mt. Fugen and M. sinensis on Mt. Sakurajima) were sampled with a sterilized scoop. The samples were transported to the laboratory in sterilized boxes within one day after sampling, frozen with liquid $\mathrm{N}_{2}$, and stored at $-30^{\circ} \mathrm{C}$ until analysis. For the root samples, the adhering soil particles were removed by gentle shaking in sterile water and with tweezers, then the roots from four plants

Key Words: Andisols, bacterial community, rhizobacterium of pioneer plants, 16S rRNA, volcanogenous regosols.

${ }^{1}$ Present address: Graduate School of Agricultural and Life Sciences, The University of Tokyo, Bunkyo-ku, Tokyo, 113-8657 Japan. 
were cut into pieces before freezing. A portion of soil samples of Mt. Fugen was used for a pot experiment. The soil $(800 \mathrm{~g})$ was placed in a pot $(11.5 \mathrm{~cm} \phi, 16 \mathrm{~cm}$ height), and five seeds of Polygonum sp. were sown and cultivated in a greenhouse with $60 \mathrm{~mL}$ of water a day, an amount nearly equivalent to the average daily precipitation at Mt. Fugen. At $75 \mathrm{~d}$ after

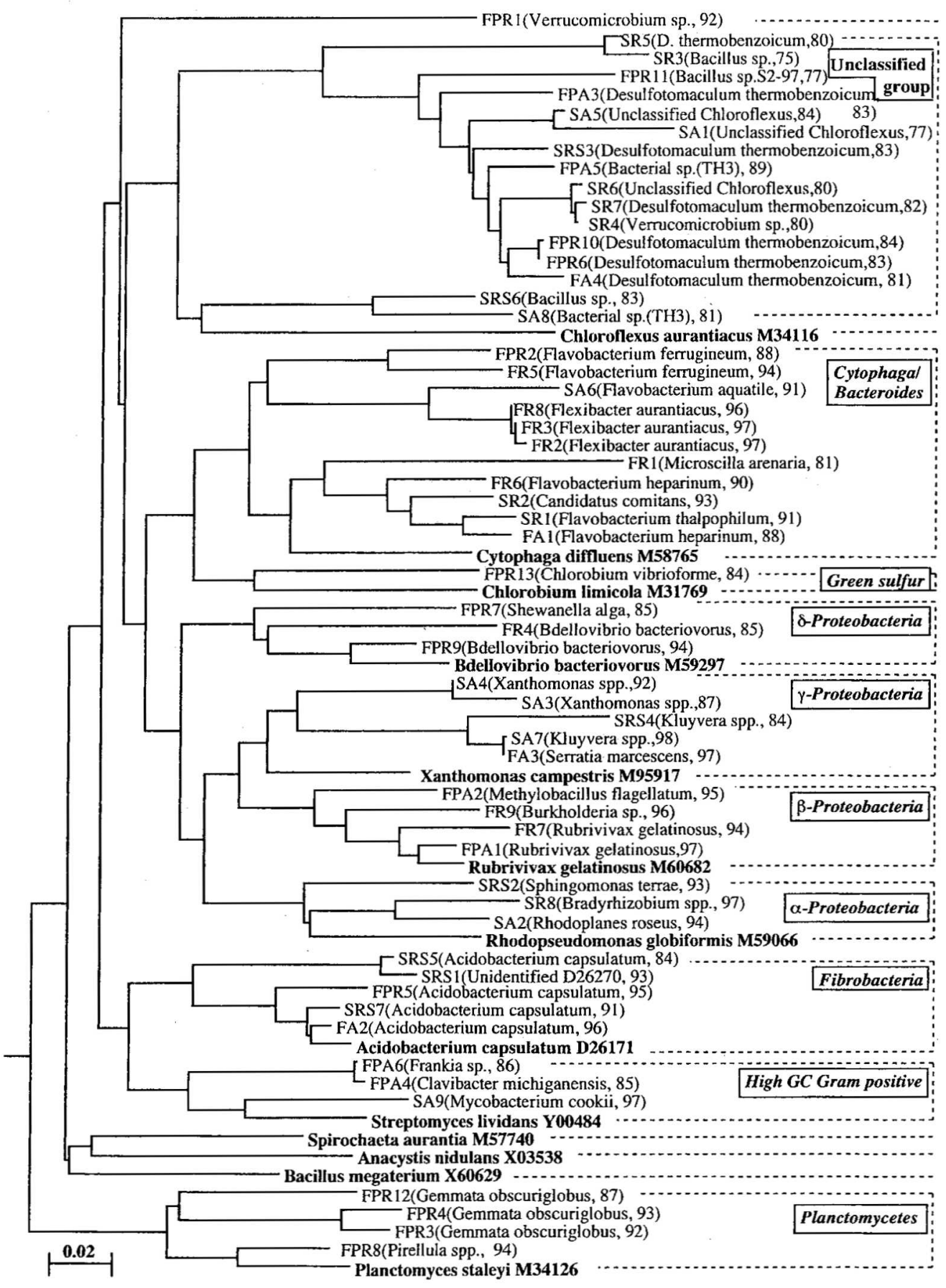


cultivation, the non-rhizosphere soil, rhizosphere soil obtained by gentle shaking of the roots in the air, and roots were sampled.

DNA was directly extracted from $2 \mathrm{~g}$ portions of soil (dry wt.) or of root pieces (fresh wt.) by the method of Zhou et al. (1996). Extracted DNA was purified through low-melting agarose gel (Porteous and Armstrong 1993). A part of 16S rDNA (positions 530-1494 in Escherichia coli numbering) in purified DNA corresponding to $50 \mathrm{mg}$ of soil or root was amplified by PCR (TaKaRa Ex Taq polymerase $2 \mathrm{U}$, primers $0.5 \mu \mathrm{M}$ each, dNTP $0.2 \mathrm{mM}$ each, $10 \times E x$ Taq buffer containing $20 \mathrm{mM} \mathrm{Mg} \mathrm{Mg}^{2+} 5 \mu \mathrm{L}$, total $50 \mu \mathrm{L}$ ). The primers were 5'-GTGCCAGCMGCCGCGG-3' as forward primer and 5'-GGYTACCTTGTTACGACTT $-3^{\prime}$ as reverse primer, both of which being universal primers (Borneman et al. 1996). The reaction conditions were: $2 \mathrm{~min}$ at $90^{\circ} \mathrm{C}, 40$ cycles of $1 \mathrm{~min}$ at $94^{\circ} \mathrm{C}, 0.5 \mathrm{~min}$ at $55^{\circ} \mathrm{C}$, and 2.5 min at $70^{\circ} \mathrm{C}$, and $10 \mathrm{~min}$ at $70^{\circ} \mathrm{C}$. The amplified fragments were cloned into the pT7 Blue-T vector (Novagen). The ligated plasmids were transformed into competent $E$. coli JM109. Nineteen clones from immature volcanic ash soils, 30 clones from roots, and 7 clones from rhizosphere soil were analyzed with an automated DNA sequencer (ABI PRISM 377, Perkin-Elmer) using the PCR reverse primer as sequencing primer. The nucleotide sequence data reported in this paper will appear in the DDBJ/EMBL/GenBank database (AB005820$\mathrm{AB} 005876$ ). Phylogenetic relationships among the sequences of the clones (positions 11671420 in $E$. coli numbering) and the 14 bacterial strains in the DNA databases were analyzed using the CLUSTAL W program (Thompson et al. 1994) and the neighbor-joining method

Table 1. Distribution of partial $16 \mathrm{~S}$ rDNA clones from immature volcanic ash soil area within the domain Bacteria.

\begin{tabular}{|c|c|c|c|c|c|c|c|c|c|c|c|c|}
\hline Sample ${ }^{a}$ & $\begin{array}{c}\text { Pro } \\
\alpha\end{array}$ & $\begin{array}{c}\text { oteob } \\
\beta\end{array}$ & & $\delta_{B}$ & $\begin{array}{c}\text { Cyto- } \\
\text { phaga/ } \\
\text { Bacteroides }\end{array}$ & $\begin{array}{c}\text { High GC } \\
\text { Gram } \\
\text { positive }\end{array}$ & $\begin{array}{l}\text { Plancto- } \\
\text { mycetes }\end{array}$ & $\begin{array}{c}\text { Fibro- } \\
\text { bacteria }\end{array}$ & $\begin{array}{c}\text { Un- } \\
\text { classified }\end{array}$ & $\begin{array}{c}\text { Green } \\
\text { sulfur } \\
(\text { Chlorobium })\end{array}$ & $\begin{array}{l}\text { Verruco- } \\
\text { micro- } \\
\text { bium }\end{array}$ & Total \\
\hline FA & 0 & 0 & 1 & 0 & 1 & 0 & 0 & 1 & 1 & 0 & 0 & 4 \\
\hline FR & 0 & 2 & 0 & 1 & 6 & 0 & 0 & 0 & 0 & 0 & 0 & 9 \\
\hline FPA & 0 & 2 & 0 & 0 & 0 & 2 & 0 & 0 & 2 & 0 & 0 & 6 \\
\hline FPR & 0 & 0 & 0 & 2 & 1 & 0 & 4 & 1 & 3 & 1 & 1 & 13 \\
\hline $\mathrm{SA}$ & 1 & 0 & 3 & 0 & 1 & 1 & 0 & 0 & 3 & 0 & 0 & 9 \\
\hline $\mathrm{SR}$ & 1 & 0 & 0 & 0 & 2 & 0 & 0 & 0 & 5 & 0 & 0 & 8 \\
\hline SRS & 1 & 0 & 1 & 0 & 0 & 0 & 0 & 3 & 2 & 0 & 0 & 7 \\
\hline Total & 3 & 4 & 5 & 3 & 11 & 3 & 4 & 5 & 16 & 1 & 1 & 56 \\
\hline
\end{tabular}

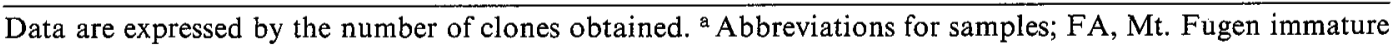
volcanic ash soil; FR, Mt. Fugen Polygonum cuspidatum roots; FPA, Mt. Fugen immature volcanic ash soil in pot experiment; FPR, Paspalum sp. roots in pot experiment; SA, Mt. Sakurajima immature volcanic ash soil; SR, Mt. Sakurajima Miscanthus sinensis roots; SRS, Mt. Sakurajima soil from. rhizosphere of $M$. sinensis.

Fig. 1. Phylogenetic relationships of partial 16S rDNA sequences (positions 1167-1420, E. coli numbering) from 56 clones in immature volcanic ash soil area and 13 bacteria in DNA databases (bold, with their accession number). FA, Mt. Fugen immature volcanic ash soil; FR, plant roots in Mt. Fugen; FPA, immature volcanic ash soil in pot experiment; FPR, roots in pot experiment; SA, Mt. Sakurajima immature volcanic ash soil; SR, roots in Mt. Sakurajima; SRS, rhizosphere soil in Mt. Sakurajima. As for the environmental clones, the name of known organism closest to each clone and the percentage of homology were shown in parenthesis. Names of the known major groups in the domain Bacteria, with the exception of an unclassified group, were shown in boxes, and the range of each group was indicated by a dashed line. Bar indicates the number of changes per sequence. 
(Saitou and Nei 1987). Methanococcus thermolithotrophicus (M59128) was used as root in the tree. The FASTA program (Pearson and Lipman 1988) was run for the homology search. According to the tree and the homology value, each clone was assigned to one of the major groups of the domain Bacteria (Olsen et al. 1994).

Distribution of the clones from immature volcanic ash soil area among the major groups of Bacteria is shown in Table 1, and their relationships and results of homology search are indicated in Fig. 1. Similarity of the clones to the most related strains in the database was 75-97\%. Sixteen out of 56 sequences did not correspond to those of the known major groups of Bacteria, as reported in previous studies in the field of molecular, soil microbial diversity (Stackebrandt et al. 1993; Ueda et al. 1995; Borneman et al. 1996).

Bacterial 16S rDNA sequences from a variety of groups were recovered in the immature volcanic ash soil area (Table 1). Although the bacterial community structure could not be determined precisely by the methods used in this study due to the bias during DNA extraction and PCR amplification (Smit et al. 1997) as well as the limited number of the clones analyzed, the results obtained at least indicate the existence of bacteria with the sequences. Therefore, the results suggest that various bacteria occurred in the immature volcanic ash soil area.

The results obtained showed that Acidobacterium- and Planctomycetes-like bacteria were present in the immature volcanic ash soil area (Fig. 1). So far, Acidobacterium capsulatum has been isolated only from an acidic mine (Kishimoto et al. 1991). It has been recently suggested that Planctomycetes occurred profusely in soils in an uncultured form (Lee et al. 1996; Zarda et al. 1997). The results obtained in this report may raise questions regarding their role in the immature volcanic ash soil area.

Our primary concern is to determine whether the bacterial community is ecologically important in terms of the genesis and development of volcanic ash soils. Yoshida (1989) reported that initial colonizers of culturable bacteria in a new tephra of Usu Volcano in Japan consisted of Arthrobacter, Corynebacterium, and Streptomyces. Actinomycetes were reported to be relatively abundant in volcanogenous soils (Ishizawa and Toyoda 1964). In the present study, one Clavibacter (formerly Corynebacterium)-like clone was recovered while other easily culturable actinomycetes or high GC Gram positive bacteria were not detected. It is suggested that the bacterial community may change toward a community rich in high GC Gram positive bacteria along with soil formation.

Acknowledgments. We thank the members of Nagasaki Prefecture, Mr. K. Yamamoto at Central Service Co., Prof. Dr. S. Kanazawa at Kagoshima University, and Mr. N. Kohno at Yamaguchi University for their assistance in sampling.

\section{REFERENCES}

Borneman, J., Skroch, P.W., O'Sullivan, K.M., Palus, J.A., Rumjanek, N.G., Jansen, J.L., Nienhuis, J., and Triplett, E.W. 1996: Molecular microbial diversity of an agricultural soil in Wisconsin. Appl. Environ. Microbiol., 62, 1935-1943

FitzPatrick, E.A. 1980: Soils. Their Formation, Classification and Distribution, Longman Group Ltd., London

Ishizawa, S. and Toyoda, H. 1964: Microflora of Japanese soils. Bull. Natl. Inst. Agric. Sci. Ser. B, 14, 203284 (in Japanese with English summary)

Kishimoto, N., Kosako, Y., and Tano, T. 1991: Acidobacterium capsulatum gen. nov., sp. nov.: An acidophilic chemoorganotrophic bacterium containing menaquinone from acidic mineral environment. Curr. Microbiol., 22, 1-7 
Lee, S.-Y., Bollinger, J., Bezdicek, D., and Ogram, A. 1996: Estimation of the abundance of an uncultured soil bacterial strain by a competitive quantitative PCR method. Appl. Environ. Microbiol, 62, 3787-3793

Olsen, G.J., Woese, C.R., and Overbeek, R. 1994: The winds of (evolutionary) change: Breathing new life into microbiology. J. Bacteriol., 176, 1-6

Pearson, W.R. and Lipman, D.J. 1988: Imported tools for biological sequence comparison. Proc. Natl. Acad. Sci. U.S.A., 85, 2444-2448

Porteous, L.A. and Armstrong, J.L. 1993: A simple mini-method to extract DNA directly from soil for use with polymerase chain reaction amplification. Curr. Microbiol., 27, 115-118

Saitou, N. and Nei, M. 1987: The neighbor-joining method: A new method for reconstructing phylogenetic trees. Mol. Biol. Evol., 4, 406-425

Smit, E., Leeflang, P., and Wernars, K. 1997: Detection of shifts in microbial community structure and diversity in soil caused by copper contamination using amplified ribosomal DNA restriction analysis. FEMS Microbiol. Ecol., 23, 249-261

Stackebrandt, E., Liesack, W., and Goebel, B.M. 1993: Bacterial diversity in a soil sample from a subtropical Australian environment as determined by $16 \mathrm{~S}$ rDNA analysis. FASEB J., 7, 232-236

Thompson, J.D., Higgins, D.G., and Gibson, T.J. 1994: CLUSTAL W: improving the sensitivity of progressive multiple sequence alignment through sequence weighting, position-specific gap penalties and weight matrix choice. Nucl. Acids Res., 22, 4673-4680

Ueda, T., Suga, Y., and Matsuguchi, T. 1995: Molecular phylogenetic analysis of a soil microbial community in a soybean field. Eur. J. Soil Sci., 46, 415-421

Yoshida, T. 1989: Changes in microflora in new tephra of the Usu Volcano. Trans. Mycol. Soc. Jpn., 30, 3549 (in Japanese with English summary)

Zarda, B., Hahn, D., Chatzinota, A., Schonhuber, W., Neef, A., Amann, R.I., and Zeyer, J. 1997: Analysis of bacterial community structure in bulk soil by in situ hybridization. Arch. Microbiol., 168, 185-192

Zhou, J., Bruns, M.A., and Tiedje, J.M. 1996: DNA recovery from soils of diverse composition. Appl. Environ. Microbiol., 62, 316-322 